\title{
A debreceni Orvostudományi Kar elmaradt negyedszázados jubileuma 1943-44-ben
}

\author{
Mudrák József dr.
}

Az első világháború kitöréséig Magyarországon csak két egyetem múködött, mégpedig Budapesten és Kolozsvárott, mindkettő orvostudományi karral, ugyanis abban az időszakban egy orvosi karral nem rendelkező egyetemet nem teljes értékü, hanem úgynevezett „csonka” egyetemnek tartottak.

Debrecenben és Pozsonyban az 1912. évi XXXVI. törvénycikk alapján létesült egyetem, amely 1914 őszén megnyílt, de orvosi kar nélkül. Tekintettel a szükséges klinikai építkezésekre, orvostudományi kar létesítését csakis „fokozatos fejlesztés” után tartották kivihetőnek.

Bár a klinikaépületek fele még részben sem volt készen, mégis 1918-ban mindkét helyen megalakult az orvoskar. Debrecenben már az 1916-ban kinevezett szülészprofesszor, Kenézy Gyula (1860-1931) (aki a klinikai építkezések miniszteri biztosa is volt) mellé IV. Károly király 1918. szeptember 18-án nevezte ki Orsós Ferencet (1879-1962) a kórbonctan, Verzár Frigyest (18861979) a kórtan és Vészi Gyulát (1888-1918) az élettan nyilvános rendes tanárává, illetve egyszersmind a megfelelő intézetek igazgatójává.

A négy professzor 1918. október 19-én - a fennmaradt jegyzőkönyv tanúsága szerint - egyhangú határozattal kimondta, hogy „a debreceni magyar királyi tudományegyetem orvosi karát ezennel megalakítja”. A forradalmi események és a Tiszántúl román megszállása miatt azonban az orvosképzés csak 1921 őszén indulhatott meg [1].

A pécsi Erzsébet Tudományegyetem Orvostudományi Karának (amely az 1919-ben, a csehszlovák állam által megszüntetett pozsonyi Erzsébet Tudományegyetem Orvostudományi Karának jogutódja volt) [2] huszonöt éves jubileumán, 1943 májusában a debreceni orvosi kar képviseletében Jeney Endre (1891-1970) prodékán vett részt.

Visszatérve Debrecenbe a következő, május 12-ei kari ülésen Jeney javasolta, hogy a debreceni orvosi kar is ülje meg 25 éves fennállásának évfordulóját. Went István (1899-1963) dékán javaslatára a jubileumi ünnepély előkészítésére egy hármas, majd egy négyes bizottság létesül, amelynek tagjai Hüttl Tivadar (1884-1955) sebészprofesszor, mint elnök, mellette Bodnár János (1889-1953) orvosi vegytani, Jeney Endre közegészség- tani és Borsos-Nachtnébel Ödön (1894-1951) kórbonctani professzorok voltak [3].

Az ünnepséget az 1943/44-es tanév első felére tervezték, előbb októberre, majd novemberre, ünnepi fó előadóul pedig a kar alapító professzorát, az akkor már Budapesten múködő Orsós Ferencet kérték fel.

Azonban az 1943. októberi kari ülésen az új tanév dékánja, Borsos-Nachtnébel Ödön kénytelen volt bejelenteni, hogy: „A VK. [Vallás- és Közoktatásügyi] Miniszter Úr a jubileumi ünnepség megtartását nem tartja idószerünek s azt javasolja, hogy az orvostudományi kar 25 éves fennállásáról emlékkönyv kiadásával emlékezzék meg.”

A kari tanács tagjai elfogadták a változtatást és ugyanazt a bizottságot bízták meg az emlékkönyv elkészítésével [4].

A bizottság decemberre készítette el a kötet felépítésére vonatkozó javaslatát, leadási határidőül 1944. április 15-ét jelölve meg a következő tartalmi felosztással:

„1. Dékáni elöszó (kb. 2 oldal).

2. Az orvostudományi kar 25 éves története (kb. 40-50 oldal).

3. Az orvostudományi kar egyes klinikái és intézetei fejlödésének, múltjának és jelenének ismertetése a tudományos munkásság adatszeri" felsorolásával (szerzö neve, a dolgozat cime, megjelenés belye és ideje). Klinikánként és intézetenként átlag 10 oldal. Összesen 19 klinika, illetöleg intézetröl lenne szó, ha az összevont tanszékek intézeteit külön számitjuk és tekintetbe vesszük a megszünt Röntgen intézetet is. Az egyetemi gyógyszertárral együtt 20 intézmény jönne számitásba.

4. A volt és jelenlegi tanárok egy-egy tudományos dolgozata. Egyenként átlag 15 oldal, 24 tanárról lévén szó, ez a rész $k b .400$ oldalt tenne ki.

Az egész kötet terjedelme tehát 6-700 oldal lenne" [5].

A dékán minisztériummal folytatott sorozatos tárgyalásokat, amely során ugyan a miniszter 7000 pengőt helyezett kilátásba a kötetre, de cserébe a legtöbb helyet elfoglaló tudományos résznek el kellene maradnia.

A kitűzött határidőre csak Benedek László (18871945), Gyulai Zoltán (1887-1968), Neuber Ede (18821946), Verzár Frigyes és Wodetzky József (1872-1956) volt debreceni professzorok küldtek be tudományos dolgozatokat, és három egység (a Belgyógyászati, a Fül-orr- 


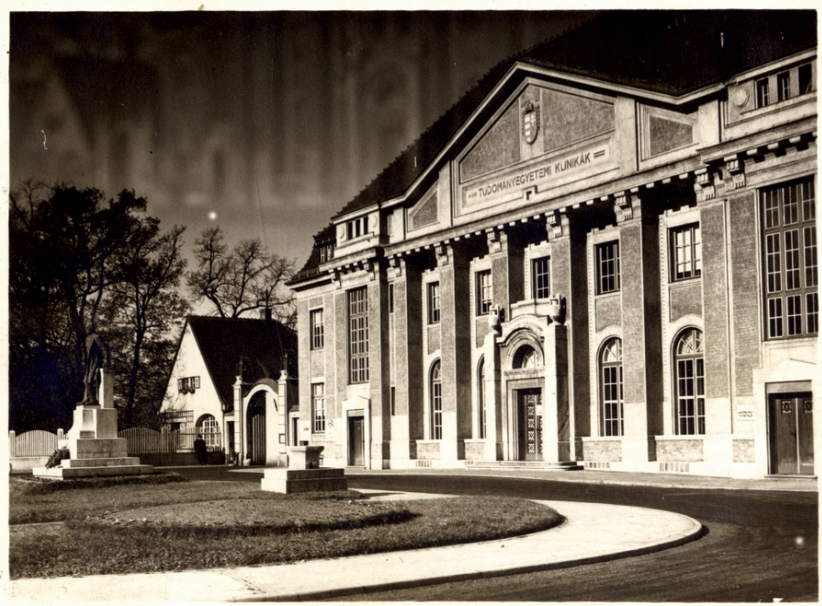

1. ábra

A debreceni Tisza István Tudományegyetem klinikai telepének úgynevezett Felvételi Épülete az 1930-as években, előtérben Tisza István szobra (Kisfaludy Stróbl Zsigmond alkotása). Közlés a Debreceni Egyetemi és Nemzeti Könyvtár (DEENK) elektronikus archívumának (DEA) gyújteményéből

gégegyógyászati Klinika és az Egyetemi Gyógyszertár) vezetői írták meg történetüket. (Szerencsére a dolgozatok a kari iktatott iratok között, a Hajdú-Bihar Megyei Levéltárban fennmaradtak [6]!)

Azonban ekkor már a háborús viszonyok hatásai felerősödtek, a katonai behívások miatt már egyre kevesebb orvos maradt a klinikákon, a megmaradt oktatók és tisztviselők a bekövetkező bombázások elleni biztonság keresésével voltak elfoglalva.

A tanév utolsó kari tanácsülésén, 1944 júniusában Borsos-Nachtnébel dékán rezignáltan jelentett be, hogy: „A kari jubileumi évkönyv egybeállitása és megjelentetése érdekében mindent megtett, azonban a rendkivïli események ebben a törekvésében meggátolták, úgyhogy a megjelentetés a jövö tanévi dékánt fogja terhelni.” [7].

A következő tanévre ugyanekkor megválasztott Csilléry András (1883-1964) dékán azonban már nem foglalkozhatott a jubileumi évkönyvvel: a háborús események, a rövidített orvosi tanfolyamok kihelyezése Halléba, majd az addigi rendszer teljes összeomlása elsodortak mindent...

\section{Irodalom}

[1] Kapusz, N., Petrovics, A., Vásárhelyi, F.: Ninety years of medical education in Debrecen. [Kilencvenéves a debreceni orvosképzés.] Debreceni Egyetem, Orvos- és Egészségtudományi Centrum, Debrecen, 2008. [Hungarian]

[2] Kiss, L.: Once upon a time there was a medical faculty - A "brief history" of the Medical Faculty of the Erzsébet University in Pressburg (1914-1919). [Volt egyszer egy orvosi kar - a pozsonyi Erzsébet Egyetem Orvosi Karának „rövid története” (19141919).] Comm. de Hist. Artis Med., 2010, 56(210-213), 205214. [Hungarian]

[3] Royal Hungarian Stephen Tisza University in Debrecen (= STUD), Faculty of Medicine Records, May 12, 1943. IX. Regular Session, Point V/16/9. University of Debrecen, Archive, Debrecen. [Debreceni m. kir. Tisza István Tudományegyetem (= TITE), Orvostudományi Kar, 1943. máj. 12-i IX. rendes ülés, V/16/9. pont. Debreceni Egyetem, Archívum.] [Hungarian]

[4] STUD Faculty of Medicine Records, October 13, 1943. II. Regular Session, Point IV. University of Debrecen, Archive, Debrecen. [TITE Orvostudományi Kar, 1943. október 13-i II. rendes ülés, IV. pont. Debreceni Egyetem, Archívum.] [Hungarian]

[5] STUD Faculty of Medicine Records, December 15, 1943. V. Regular Session, Point V/6./21. and enclosure No. 8. University of Debrecen, Archive, Debrecen. [TITE Orvostudományi Kar, 1943. december 15-i V. rendes ülés, V/6./21. pont és 8. sz. melléklete. Debreceni Egyetem, Archívum.] [Hungarian]

[6] Registered Papers of Faculty of Medicine VIII. 10/b. 41. d. Archive of Hajdú-Bihar County of the Hungarian National Archive: 574/1943-44. [Magyar Nemzeti Levéltár Hajdú-Bihar Megyei Levéltára, Orvoskari Iktatott Iratok, VIII. 10/b. 41. d., 574/1943-44. Debrecen.] [Hungarian]

[7] STUD Faculty of Medicine Records, Juny 14, 1944. XII. Regular Session, Point IV./1. University of Debrecen, Archive, Debrecen. [TITE Orvostudományi Kar, 1944. június 14-i XII. rendes ülés, IV./1. pont. Debreceni Egyetem, Archívum.] [Hungarian]

(Mudrák József dr.,

Debrecen, Görgey u. 16., 4032 e-mail: mudrak.jozsef@unideb.hu)

Az Orvosi Hetilap egyes számai megvásárolhatók a Mediprint Orvosi Könyvesboltban.

Cím: Budapest V., Múzeum krt. 17. - Telefon: 317-4948 